\title{
Advances in Breast Cancer - Looking Back over the Year
}

\section{Fortschritte beim Mammakarzinom - ein Rückblick auf das Jahr}

Authors

Affiliations
D. Lüftner ${ }^{1}$, M. P. Lux ${ }^{2}$, N. Maass ${ }^{3}$, F. Schütz ${ }^{4}$, I. Schwidde ${ }^{5}$, P. A. Fasching ${ }^{6}$, T. Fehm ${ }^{7}$, W. Janni ${ }^{8}$, S. Kümmel ${ }^{5}$, H.-C. Kolberg ${ }^{9}$

The affiliations are listed at the end of the article
Key words

- molecular biomarkers

- targeted therapy

- trastuzumab

- T-DM1

- everolimus

\section{Schlüsselwörter}

- Mammakarzinombehandlung

- molekulare Biomarker

- zielgerichtete Therapie

- Trastuzumab

- T-DM1

- Everolimus
- breast cancer therapy

\section{Abstract \\ $\nabla$}

Treatment options as well as the characteristics for therapeutic decisions in patients with primary and advanced breast cancer are increasing in number and variety. New targeted therapies in combination with established chemotherapy schemes are broadening the spectrum, yet not every new, promising combination achieves a better result. New data from the field of pharmacogenomics point to prognostic and predictive factors that take not only the properties of the tumour but also the genetic disposition of the patient into consideration. Current therapeutic decision-making is thus based on a combination of classical clinical and modern molecular biomarkers. Health-economic concerns are also being taken into consideration more frequently, meaning political decisions may also become a factor. This review presents the trends over the past year.

\section{Introduction}

received $\quad 2.12 .2012$

revised $\quad 3.12 .2012$

accepted 3.12.2012

Bibliography

Dol http://dx.doi.org/

10.1055/s-0032-1328084

Geburtsh Frauenheilk 2012; 72:

1117-1129 @ Georg Thieme

Verlag KG Stuttgart · New York . ISSN 0016-5751

\section{Correspondence}

Prof. Diana Lüftner

Campus Charité Mitte

Medizinische Klinik

und Poliklinik II

Hindenburgdamm 30

12200 Berlin

diana.lueftner@charite.de

\section{$\checkmark$}

Since the sequencing of the human genome around ten years ago, significant advances have been made in the molecular characterization of breast cancer [1]. This has not only helped in the development of new diagnostic tests [2]; it has also expedited the identification of new targets for drug therapy [3-5]. The last year has seen a number of studies on such new, targeted therapies, presenting significant advances in therapy, and we are seeing the first publications of works in which the entire exome has been sequenced at major collectives, and which have delivered the first insights into the genetic make-up of breast carcinoma regarding pathogenesis and progression [6-9]. We have clearly entered the genomic

\section{Zusammenfassung \\ $\nabla$}

Die Behandlungsoptionen und auch die Charakteristika zur Therapieentscheidung der Patientin mit einem primären und fortgeschrittenen Mammakarzinom werden immer vielfältiger. Neue zielgerichtete Therapien in Kombination mit etablierten Chemotherapien erweitern das Spektrum, doch potenziell vielversprechende Kombinationen bringen nicht immer ein besseres Ergebnis. Neueste Daten aus der Pharmakogenomik weisen auf Prognose- und Prädiktivfaktoren hin, die nicht nur die Eigenschaften des Tumors, sondern auch die vererbbaren genetischen Eigenschaften der Patientin berücksichtigen. Die aktuelle Therapieentscheidung ist somit mittlerweile eine Kombination aus klassischerweise klinischen und modernen molekularen Biomarkern. Immer häufiger werden auch gesundheitsökonomische Aspekte berücksichtigt, sodass auch gesundheitspolitische Überlegungen eine Rolle spielen können. Diese Übersichtsarbeit stellt die Entwicklung des vergangenen Jahres dar.

\section{Einleitung \\ $\nabla$}

Nach der Entschlüsselung des menschlichen Genoms vor etwa 10 Jahren hat die molekulare Charakterisierung des Mammakarzinoms deutliche Fortschritte gemacht [1]. Dies hat nicht nur bei der Entwicklung von neuen, diagnostischen Tests geholfen [2], sondern hat auch die Identifizierung von neuen Targets zur medikamentösen Therapie vorangetrieben [3-5]. Im letzten Jahr sind nicht nur einige Studien solcher neuer, zielgerichteter Therapien mit deutlichen Therapiefortschritten vorgestellt worden, sondern auch die ersten Arbeiten publiziert worden, die an größeren Kollektiven das komplette Exom sequenziert haben und erste Einblicke in die genetische Struktur von Mammakarzinomen in Bezug auf Pathogenese und Progression gewährt haben [6-9]. Hiermit ist 
era of breast cancer study. This review presents some of the clinically and scientifically noteworthy innovations, presentations and publications of the year.

\section{DCIS - Ductal Carcinoma in Situ}

Now that partial molecular characterization of invasive mammary carcinoma is already clinical routine, the use of simple characteristics such as oestrogen receptors, progesterone receptors and HER2 status are now a subject of discussion and scientific investigation. Extensive molecular tests have also been performed now in a study of patients with ductal carcinoma in situ (DCIS) that used 12 of the 21 markers from the work of Paik et al. [10] [11], which has been called the Oncotype ${ }^{\mathrm{TM}}$ DCIS Score. In the E5194 study, 327 patients were treated with breast-conserving surgery without subsequent radiotherapy. The study showed that, in the group of patients who underwent breast-conserving surgery without radiotherapy, the DCIS Score can deliver independent information on the risk of recurrence. This information correlates only slightly with the classical prognostic parameters of tumour size, grading and existence of comedo necrosis, and not at all with the factors menopausal status, age and clear margin. This suggests that the DCIS Score provides very real additional information.

How greatly this information will be drawn upon in clinical practice, however, in light of the typical practice in Germany of irradiating most DCIS patients after breast-conserving surgery (BCS), is questionable at best, especially seeing as the DCIS Score is merely a prognostic parameter for the risk of recurrence and not a predictive parameter for the success of radiotherapy.

Another study of DCIS patients (clinical trial RTOG 9804) presented data that could be of assistance for advising a patient with a DCIS and favourable factors with regard to radiotherapy [12]. 636 patients whose DCIS exhibited favourable prognostic parameters were randomized to receive either $50 \mathrm{~Gy}$ (RT arm) or merely observation (OBS arm). The investigators defined favourable prognostic criteria as a combination of mammographically detected lesion, grade 1 or 2, size less than $2.5 \mathrm{~cm}$ and a surgical margin greater than $3 \mathrm{~mm}$. The trial originally planned to study 1790 patients, however accrual stopped at 636 patients after nearly 7 years. At a median follow-up of 6.46 years, only 17 local recurrences were observed, of which 2 in the RT arm and 15 in the OBS arm. Over a 5-year follow-up, this equates to a local recurrence of $0.4 \%$ in the RT arm and $3.2 \%$ in the OBS arm at a hazard ratio of 0.14 and a p of 0.0022 ( Fig. 1 ).

Although the study was closed early, and overall only few events were evaluated, the data nevertheless strongly suggest that those patients with a good prognosis also benefit significantly from radiotherapy. The authors announced plans of a longer follow-up observation, where the conclusions will most likely remain the same: A "good risk" DCIS has a low risk of recurrence, yet this risk can be lowered significantly further still by radiotherapy. nun endgültig das genomische Zeitalter bei der Untersuchung der Krankheit Mammakarzinom eingeläutet. Diese Übersichtsarbeit reflektiert einige der Neuigkeiten, Präsentationen und Publikationen, die im letzten Jahr entweder klinisch oder wissenschaftlich aufgefallen sind.

\section{DCIS - duktales Carcinoma in situ \\ $\nabla$}

Nachdem die teilweise molekulare Charakterisierung des invasiven Mammakarzinoms bereits in der klinischen Routine erfolgt, ist die Nutzung von einfachen Charakteristika wie Östrogenrezeptor, Progesteronrezeptor oder HER2-Status unter Diskussion und Gegenstand wissenschaftlicher Untersuchungen. Umfangreichere molekulare Untersuchungen wurden nun auch an einer Studie mit DCIS (duktales Carcinoma in situ)-Patientinnen durchgeführt, die 12 der 21 Marker aus der Arbeit von Paik et al. [10] verwendete [11], welcher Oncotype ${ }^{\mathrm{TM}}$ DCIS Score genannt wurde. In der E5194-Studie wurden 327 Patientinnen mit brusterhaltender Therapie ohne nachfolgende Radiatio therapiert. Es konnte gezeigt werden, dass der DCIS Score in der Gruppe der nicht bestrahlten, brusterhaltend operierten Patientinnen eine unabhängige Information über das Rezidivrisiko liefern kann. Diese Information korrelierte nur mäßig mit den klassischen Prognoseparametern Tumorgröße, Grading und Vorliegen von Komedonekrosen und überhaupt nicht mit den Faktoren Menopausenstatus, Alter und freier Randsaum. Insofern ist wohl von einer echten $\mathrm{Zu}$ satzinformation durch den DCIS Score auszugehen.

Inwiefern allerdings vor dem Hintergrund der in Deutschland üblichen Praxis, die meisten Patientinnen mit DCIS nach brusterhaltender Chirurgie (BCS) zu bestrahlen, diese Information eine große Rolle in der klinischen Praxis spielen wird, ist zumindest fraglich, zumal der DCIS Score ja auch nur ein Prognoseparameter für das Rezidivrisiko und kein prädiktiver Parameter für den Erfolg einer Bestrahlung ist.

Eine andere Studie mit DCIS-Patientinnen (RTOG 9804-Studie) stellte Daten vor, die für die Beratung einer Patientin mit einem DCIS und günstigen prognostischen Faktoren im Hinblick auf die Bestrahlung eine Hilfe darstellen kann [12]. 636 Patientinnen, deren DCIS günstige Prognoseparameter aufwies, erhielten randomisiert entweder eine Ganzbrustbestrahlung mit 50 Gy oder nur eine Nachsorge (Beobachtung). Als günstige Prognosekriterien definierten die Untersucher eine Kombination aus mammografisch detektierter Läsion, Grading 1 oder 2, Größe unter 2,5 cm und einem freien Randsaum von über $3 \mathrm{~mm}$. Ursprünglich waren 1790 Patientinnen geplant, allerdings wurde die Rekrutierung nach fast 7 Jahren mit 636 Patientinnen eingestellt. Insgesamt wurden bei einem medianen Follow-up von 6,46 Jahren nur 17 Lokalrezidive beobachtet, davon 2 im Bestrahlungsarm und $15 \mathrm{im}$ Beobachtungsarm. Bezogen auf ein 5-Jahres-Follow-up ergibt sich eine Lokalrezidivrate von 0,4\% im Bestrahlungsarm und $3,2 \%$ im Beobachtungsarm bei einer Hazard Ratio von 0,14 und einem p von 0,0022 ( $\odot$ Abb. 1).

Auch wenn die Studie früher geschlossen wurde und insgesamt nur wenige Ereignisse ausgewertet werden konnten, sprechen die Daten dafür, dass auch die Patientinnen mit einer guten Prognose von der Bestrahlung signifikant profitieren. Die Autoren kündigten eine längere Follow-up-Beobachtung an, wobei die Schlussfolgerungen wahrscheinlich gleich bleiben werden: Ein DCIS mit günstigen Prognosefaktoren hat eine geringe Rezidivgefahr, gleichwohl lässt sich dieses Risiko durch eine Bestrahlung signifikant weiter senken. 


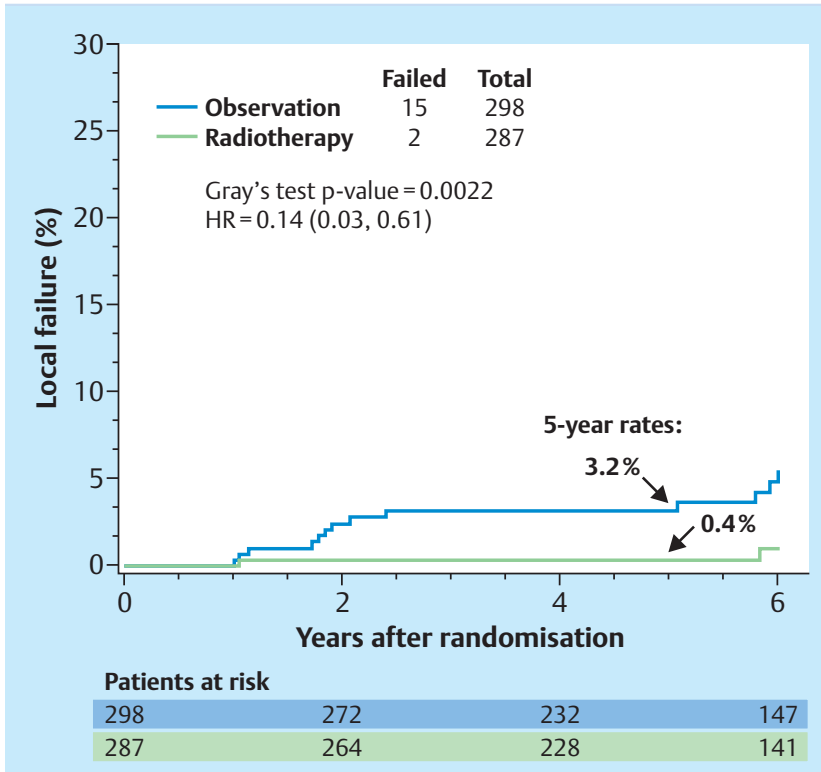

Fig. 1 Local recurrence-free survival in the RTOG 9804 study (adapted from [12]). (HR: hazard ratio).

\section{Treatment of HER2-positive Patients in Palliative and Curative Situations}

\section{Lapatinib not suitable as first-line therapy}

in metastatic situations

The monoclonal antibody trastuzumab $(\mathrm{T})$ has been standard in first-line therapy for HER2-positive, metastatic breast cancers for many years. A recently published trial (MA.31) presented a direct comparison with the tyrosine kinase inhibitor lapatinib (L), which is approved for use in combination with capecitabine (C) to treat progression of the disease after trastuzumab therapy [13]. MA.31 studied 636 patients with advanced breast cancer, who received paclitaxel $\left(80 \mathrm{mg} / \mathrm{m}^{2}\right.$ weekly) or docetaxel $(75 \mathrm{mg} /$ $\mathrm{m}^{2} \mathrm{q} 3 \mathrm{w}$ ) for 24 weeks in combination with either trastuzumab or lapatinib. After a median follow-up of 13.6 months, the lapatinib combination exhibited significantly inferior efficacy in the ITT population: Median progression-free survival (PFS) was 8.8 months, compared to 11.4 months in the trastuzumab + taxane arm, and thus exhibited a higher hazard ratio ( $\mathrm{HR}=1.33 ; 95 \% \mathrm{CI}$ : 1.06-1.67; $p=0.01$; $O$ Fig. 2 ). In the group of patients with centrally confirmed positive HER2 status $(n=525)$, this difference was even greater (HR 1.48; $95 \%$ CI: $1.15-1.92 ; \mathrm{p}=0.003$ ). No statistically significant difference in overall survival was observed $(\mathrm{HR}=1.1 ; 95 \% \mathrm{CI}: 0.75-1.61 ; \mathrm{p}=0.62)$. Regarding adverse events, more grade $3 / 4$ diarrhoea events and rashes were observed under lapatinib + taxane $(\mathrm{p}<0.001)$, as well as more discontinuations of therapy (17.8 vs. $10.6 \%$ ). Given this inferior efficacy, the trial was closed after this interim analysis; there will be no further follow-up observation as originally planned.

These results change nothing for first-line therapy of advanced breast cancer; this setting is already not an approved indication for the use of lapatinib.

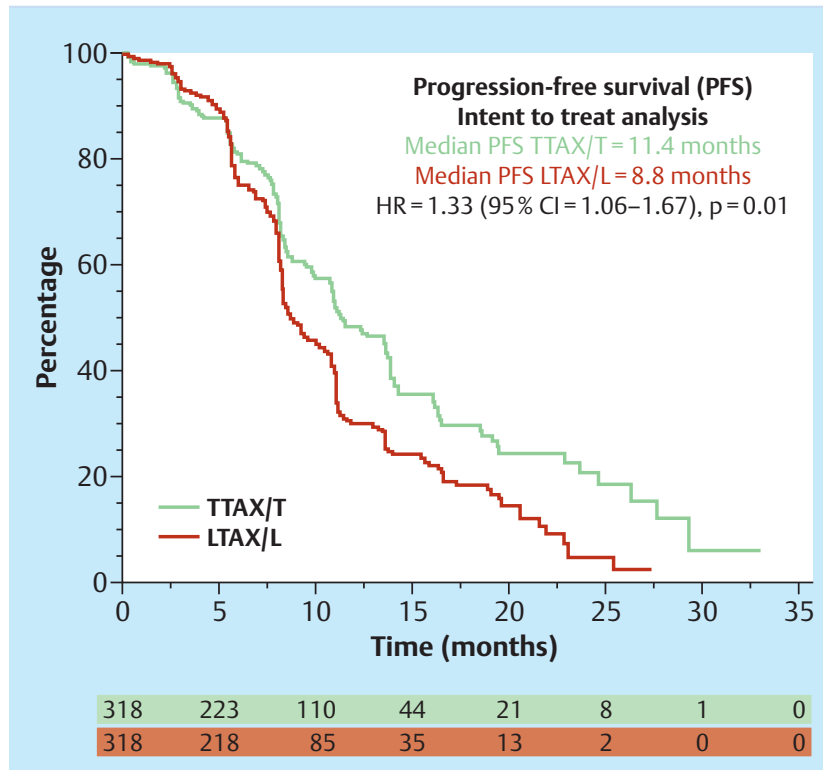

Fig. 2 Progression-free survival in the MA.31 study (adapted from [13]) (TTAX/T: taxane with trastuzumab, LTAX/L: taxane with lapatinib, HR: hazard ratio).

\section{Behandlung von HER2-positiven Patientinnen in der palliativen und kurativen Situation}

\section{Lapatinib als First-Line-Therapie in der metastasierten Situation nicht geeignet}

Der monoklonale Antikörper Trastuzumab (T) ist seit vielen Jahren Standard in der First-Line-Therapie des HER2-positiven, metastasierten Mammakarzinoms. Ein direkter Vergleich mit dem Tyrosinkinasehemmer Lapatinib (L), welcher in Kombination mit Capecitabin (C) für die Behandlung nach Fortschreiten der Erkrankung nach einer Trastuzumabbehandlung zugelassen ist, wurde in einer kürzlich veröffentlichten Studie (MA.31) vorgestellt [13]. MA.31 schloss 636 Patientinnen mit fortgeschrittenen Mammakarzinom ein, die Paclitaxel ( $80 \mathrm{mg} / \mathrm{m}^{2}$ wöchentlich) oder Docetaxel $\left(75 \mathrm{mg} / \mathrm{m}^{2} \mathrm{q} 3 \mathrm{w}\right.$ ) für 24 Wochen, entweder in Kombination mit Trastuzumab oder mit Lapatinib, erhielten. Nach einem medianen Follow-up von 13,6 Monaten zeigte sich in der ITT-Population eine signifikante Unterlegenheit der Lapatinib-Kombination: Das progressionsfreie Überleben lag bei median 8,8 Monaten verglichen mit 11,4 Monaten unter Trastuzumab + Taxan und hatte somit ein höheres Rückfallrisiko ( $H R=1,33$; $95 \%$-KI: 1,06-1,67; $p=0,01 ; \bigcirc$ Abb. 2). In der Gruppe der Patientinnen mit zentral gesichertem positiven HER2-Status $(n=525)$ fiel dieser Unterschied noch größer aus (HR 1,48; 95\%-KI: 1,15-1,92; $p=0,003$ ). Auch beim Gesamtüberleben konnte kein statistisch signifikanter Unterschied gesehen werden. (HR=1,1; 95\%-KI: 0,75-1,61; $p=0,62$ ). Hinsichtlich der Verträglichkeit wurden unter Lapatinib + Taxan mehr Grad-3/4-Diarrhöen und Hautrötungen beobachtet $(p<0,001)$, und es kam zu mehr Therapieabbrüchen (17,8 vs. 10,6\%). Aufgrund der Unterlegenheit wurde die Studie nach dieser Interimsanalyse abgebrochen; eine ursprünglich geplante weitere Nachbeobachtung wird nicht erfolgen.

Für die Erstlinientherapie des fortgeschrittenen Mammakarzinoms ändert sich durch diese Ergebnisse am gegenwärtigen Standard nichts; für Lapatinib ist der Einsatz in diesem Setting ohnehin keine zugelassene Indikation. 


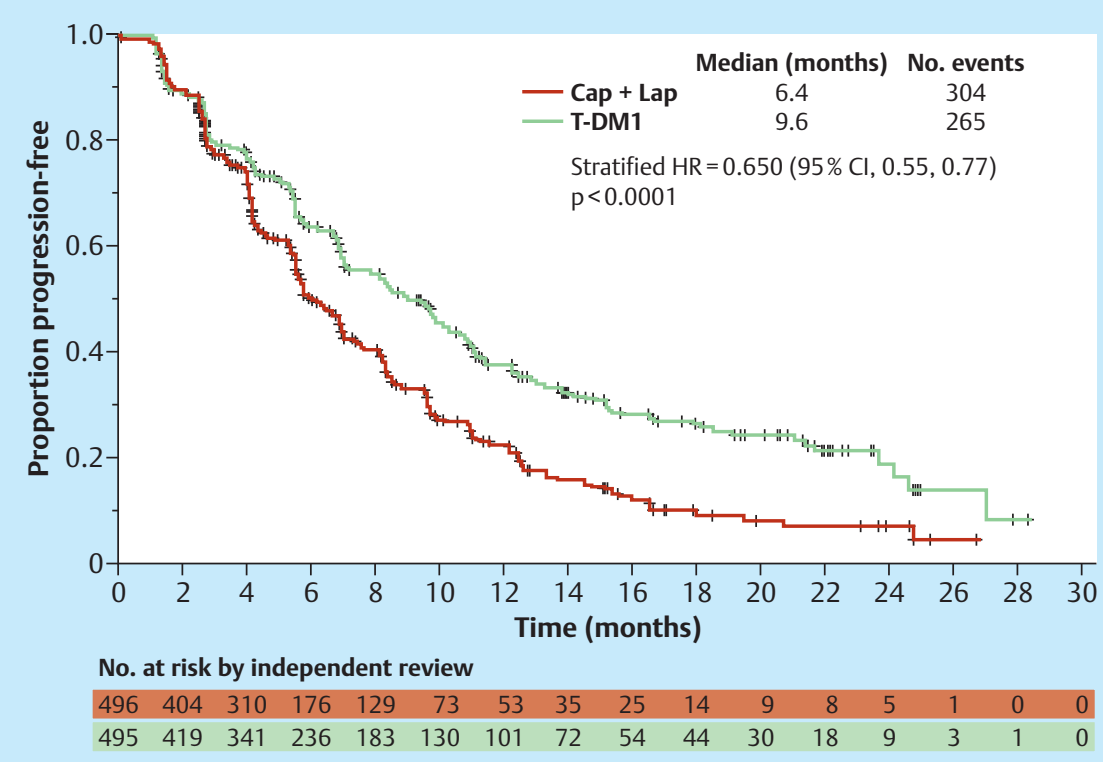

Fig. 3 Initial results for progression-free survival in the EMILIA study (adapted from [14]) (T-DM1: trastuzumab-maytansin, Cap: capecitabine, Lap: lapatinib, HR: hazard ratio).

Stratified $\mathrm{HR}=0.650(95 \% \mathrm{Cl}, 0.55,0.77)$

$\begin{array}{rrrrrrrrrrrrrrrr}496 & 404 & 310 & 176 & 129 & 73 & 53 & 35 & 25 & 14 & 9 & 8 & 5 & 1 & 0 & 0 \\ 495 & 419 & 341 & 236 & 183 & 130 & 101 & 72 & 54 & 44 & 30 & 18 & 9 & 3 & 1 & 0\end{array}$

Anti-HER2 responses in metastatic patients

after adjuvant trastuzumab therapy

Patients with HER2-positive, intermediate or high-risk breast cancer receive trastuzumab in the adjuvant setting alongside chemotherapy for the duration of one year. Until now, there had hardly been any data on how greatly adjuvant trastuzumab therapy influences the response to HER2-targeted therapy in the metastatic setting. A retrospective study reports of 523 patients with HER2-positive breast cancer with distant metastasis. 76 of these patients had already received adjuvant trastuzumab treatment. While $48 \%$ of the trastuzumab-naïve, metastatic patients achieved a response, only $13 \%$ of patients previously treated with trastuzumab responded to an anti-HER2 therapy plan. Furthermore, the overall survival was significantly shorter for the group previously treated with trastuzumab (24 vs. 39 months; $\mathrm{p}=0.029$ ). This study highlights the importance of studies in this specific therapy setting.

\section{New effective anti-HER2 substance}

for treating metastatic patients who have received prior trastuzumab treatment

The EMILIA study $[14,15]$ compared T-DM1 monotherapy with capecitabine and lapatinib. T-DM1 is an immunoconjugate comprising trastuzumab and the microtubule-disrupting cytotoxic agent DM1 (maytansine). This substance binds specifically to HER-2-expressing tumour cells and is internalized into the cancer cell, where the maytansine is released. The EMILIA study involved 980 patients with locally advanced or metastatic breast cancer who had received prior therapy with taxanes and trastuzumab and who developed progressive disease in the metastatic setting or within 6 months following adjuvant therapy. They received either $3.6 \mathrm{mg} / \mathrm{kg}$ i.v. q3w T-DM1 or capecitabine ( $1000 \mathrm{mg} / \mathrm{m}^{2}$ p.o. bid, days $1-14 \mathrm{q} 3 \mathrm{w}$ ) in combination with lapatinib (1.25 mg p. o. daily). Therapy continued until progression or unmanageable toxicity. The primary endpoint, progression-free survival, was significantly longer in the T-DM1 arm, at median 9.6 months, than under capecitabine/lapatinib, at median 6.4 months (HR $=0.650,95 \%$ CI: 0.55-0.77, $\mathrm{p}<0.0001$; O Fig. 3). Subgroup analyses showed that this applied to the entire patient
Anti-HER2-Ansprechen bei metastasierten Patientinnen nach adjuvanter Trastuzumab-Therapie

Patientinnen mit einem HER2-positiven Mammakarzinom mit intermediärem oder hohem Risiko erhalten in der adjuvanten Situation neben einer Chemotherapie zusätzlich für die Dauer von einem Jahr eine Trastuzumabtherapie. Bis dato gab es kaum Daten, inwieweit die adjuvante Trastuzumabtherapie das Ansprechen auf eine HER2-zielgerichtete Therapie in der metastasierten Situation beeinflusst. Eine retrospektive Studie berichtet von 523 Patientinnen mit einem HER2-positiven Mammakarzinom mit einer Fernmetastasierung. 76 dieser Patientinnen waren bereits adjuvant mit Trastuzumab behandelt worden. Während trastuzumabnaive, metastasierte Patientinnen ein Therapieansprechen von insgesamt $48 \%$ aufwiesen, sprachen lediglich nur 13\% der mit Trastuzumab vorbehandelten Patientinnen auf ein gegen HER2 zielgerichtetes Therapiekonzept an. Darüber hinaus war das Gesamtüberleben der mit Trastuzumab vorbehandelten Gruppe signifikant kürzer (24 vs. 39 Monate; p =0,029). Diese Studie unterstreicht die Wichtigkeit von Studien in dieser speziellen Therapiesituation.

Neue wirksame Anti-HER2-Substanz für die Behandlung von metastasierten Patientinnen, bei denen eine Trastuzumabvorbehandlung erfolgt war

Die EMILIA-Studie $[14,15]$ vergleicht eine T-DM1-Monotherapie mit Capecitabin und Lapatinib. erwartet. T-DM1 ist ein Immunkonjugat, bestehend aus Trastuzumab und dem an Mikrotubuli angreifenden Zytostatikum DM1 (Maytansin). Die Substanz bindet spezifisch an HER-2-exprimierende Tumorzellen und wird in die Krebszelle internalisiert, wo das Maytansin freigesetzt wird. In die EMILIA-Studie wurden 980 Patientinnen mit lokal fortgeschrittenem oder metastasiertem Mammakarzinom eingeschlossen, die mit Taxanen und Trastuzumab vorbehandelt und in der metastasierten Situation oder innerhalb von 6 Monaten nach einer adjuvanten Therapie progredient geworden waren. Sie erhielten entweder 3,6 mg/kg i.v. q3w T-DM1 oder Capecitabin $\left(1000 \mathrm{mg} / \mathrm{m}^{2}\right.$ p. o. bid, Tage 1-14 q3w) in Kombination mit Lapatinib (1,25 mg p.o. täglich). Behandelt wurde bis zur Progression oder bis zum Auftreten schwerer Nebenwirkungen. Der primäre Endpunkt, das progressionsfreie Überleben, war mit median 9,6 Monaten im T-DM1-Arm signifikant länger als unter Capecitabin/ 
population with the exception of women aged over 65. The efficacy boundary necessary for the planned interim analysis was not reached. Nevertheless, a clear trend towards improvement was observed as a result of T-DM1: After 24 months, $47.5 \%$ of all patients treated with capecitabine and lapatinib survived, while $65.4 \%$ of all patients in the T-DM1 group survived. Also, the objective response rate was significantly higher in the T-DM1 group, at $43.6 \%$, than in the capecitabine/lapatinib group, at $30.8 \%$ (difference $=12.7 \%$; $95 \% \mathrm{CI}: 6.0-19.4, \mathrm{p}=0.0002$ ). The median time to symptom progression was 7.1 months in the T-DM1 group and 4.6 months in the capecitabine/lapatinib group ( $\mathrm{HR}=0.80,95 \%$ CI: $0.67-0.95, p=0.0121)$. These data were confirmed in a second interim analysis with a later database closure [15].

These data on efficacy are especially impressive because the improvement in prognosis did not correspond to an increased rate of adverse effects. Significantly fewer dose reductions were required under T-DM1 (16.3\%) than in the control group (capecitabine $53.4 \%$; lapatinib $27.3 \%$ ); median dose intensity was $99.9 \%$ for T-DM1, 77.2\% for capecitabine and $93.4 \%$ for lapatinib. The incidence of grade 3 or higher adverse effects was lower in the T-DM1 group (40.8\%) than in the capecitabine/lapatinib group (57.0\%); and there were fewer discontinuations of treatment in the experimental arm (5.9 vs. 10.7\%) and deaths (1 vs. 5). Furthermore, the second interim analysis [15] focussed particularly on cardiac dysfunction in the two groups. The incidence of all grades, including grade 3 or higher adverse effects, were lower in the T-DM1 group $(1.8 \% / 0.2 \%)$ than in the capecitabine/lapatinib group (3.1\%/0.4\%).

This raises the question of what importance the lapatinib/capecitabine combination may have in treating metastatic breast cancer in future if the more efficacious therapy is now introduced as a first line treatment. The best sequence of anti-HER2 therapies is as yet unknown. However, given that the general clinical practice is to try to supply every patient with every available anti-HER2 treatment in the course of their therapy, and given that treatment with capecitabine/lapatinib may not be possible for those in generally poor condition, or at least not possible without compromises in dosage, this question cannot be put off for much longer.

\section{Lapatinib in the neoadjuvant therapy setting}

When it comes to neoadjuvant therapy plans, trastuzumab has become integral to the treatment plan for HER2-positive patients. The role of lapatinib or a double-blockade with both targeted substances, however, remains the subject of ongoing studies. The GeparQuinto study $[16,17]$ investigated the addition of either trastuzumab or lapatinib to standard chemotherapy in its HER2-positive arm [17]. The results were a pathological complete response (pCR) of $22.7 \%$ in the lapatinib arm and $30.3 \%$ in the trastuzumab arm.

The NeoALTTO study was based on a similar design [18], except that it featured an additional arm for a HER2 double blockade (lapatinib combined with trastuzumab). The pCR for combined treatment $(\mathrm{L}+\mathrm{T})$ and for the separate treatments $\mathrm{T}$ and $\mathrm{L}$ were $51.3,29.5$ and $24.7 \%$ respectively.

The NSABP B-41 study recently presented is very similar to the NeoALTTO study in design [19]. A total of 529 patients were involved, who received AC followed by weekly paclitaxel. Under weekly paclitaxel, the three treatment arms differed with regard to the HER2-targeted therapy plan. The patients received either lapatinib $(\mathrm{L})$, trastuzumab $(\mathrm{T})$ or both $(\mathrm{L}+\mathrm{T})$. After surgery, targeted therapy with trastuzumab was continued for a total dura-
Lapatinib mit median 6,4 Monaten (HR=0,650, 95\%-KI: 0,55-0,77, $\mathrm{p}<0,0001$; A Abb. 3). Subgruppenanalysen zeigten, dass dies für die gesamte Patientinnenpopulation galt, ausgenommen der Frauen mit einem Alter über 65 Jahren. Die für die geplante Zwischenanalyse des Gesamtüberlebens notwendige Effektivitätsgrenze war noch nicht erreicht. Dennoch zeichnet sich hier bereits ein deutlicher Trend zur Verbesserung durch T-DM1 ab: Nach 24 Monaten lebten noch 47,5\% aller Patientinnen, die mit Capecitabin und Lapatinib behandelt wurden, aber 65,4\% aller Patientinnen in der T-DM1-Gruppe. Auch die objektive Ansprechrate war in der T-DM1-Gruppe mit 43,6\% signifikant höher als in der Capecitabin/Lapatinib-Gruppe mit 30,8\% (Differenz $=12,7 \%$; 95\%-KI: 6,0-19,4, p =0,0002). Die mediane Zeit bis zur Symptomverschlechterung betrug 7,1 Monate in der T-DM1-Gruppe und 4,6 Monate in der Capecitabin/Lapatinib-Gruppe ( $H R=0,80$, 95\%-KI: 0,67-0,95, p =0,0121). In einer 2. Interimsanalyse mit einem Datenbankschluss zu einem späteren Zeitpunkt konnten die Daten bestätigt werden [15].

Diese Effektivitätsdaten beeindrucken insbesondere, da die Verbesserung der Prognose nicht mit einer erhöhten Nebenwirkungsrate einherging. Unter T-DM1 waren deutlich weniger Dosisreduktionen notwendig (16,3\%) als in der Kontrollgruppe (Capecitabin 53,4\%; Lapatinib 27,3\%); die mediane Dosisintensität betrug 99,9\% für T-DM1, 77,2\% für Capecitabin und 93,4\% für Lapatinib. Die Frequenz von Nebenwirkungen $\geq$ Grad 3 war geringer in der T-DM1-Gruppe (40,8\%) als in der Capecitabin/Lapatinib-Gruppe (57,0\%); auch kam es im experimentellen Arm zu weniger Therapieabbrüchen (5,9 vs. $10,7 \%$ ) und Todesfällen ( 1 vs. 5). Weiterhin wurde im Rahmen der 2. Interimsanalyse [15] insbesondere das Augenmerk auf kardiologische Dysfunktionen in den 2 Gruppen gelegt. Hier war die Inzidenz sowohl von allen Graden als auch von Nebenwirkungen $\geq$ Grad 3 in der T-DM1-Gruppe $(1,8 \% / 0,2 \%)$ geringer als in der Capecitabin/Lapatinib-Gruppe (3,1\%/0,4\%).

Dies wirft die Frage auf, welchen Stellenwert zukünftig die Kombination Lapatinib/Capecitabin bei der Behandlung des metastasierten Mammakarzinoms haben kann, wenn die effektivere Therapie nunmehr in eine vordere Linie eingefügt wird. Die beste Sequenz der Anti-HER2-Therapien ist bisher noch nicht bekannt. Weil jedoch in der Klinik in der Regel versucht wird, jeder Patientin im Verlauf ihrer Behandlung jede verfügbare Anti-HER2-Therapie zukommen zu lassen und weil eine Behandlung mit Capecitabin/Lapatinib bei zu schlechtem Allgemeinzustand ggf. nicht ohne Dosiskompromisse möglich sein könnte, kann diese Kombination nicht allzu weit nach hinten gestellt werden.

\section{Lapatinib in der neoadjuvanten Therapiesituation}

Im Rahmen von neoadjuvanten Therapiekonzepten ist Trastuzumab mittlerweile fester Bestandteil des Behandlungskonzepts für HER2positive Patientinnen. Die Rolle von Lapatinib bzw. die Doppelblockade mit beiden zielgerichteten Substanzen ist hingegen noch Gegenstand aktueller Studien. Die GeparQuinto-Studie untersuchte [16, 17] in ihrem HER2-positiven Arm [17] die Hinzunahme von entweder Trastuzumab oder Lapatinib zu einer Standardchemotherapie. Es konnte gezeigt werden, dass die pathologische Komplettremissionsrate im Lapatinib-Arm 22,7\% und im Trastuzumab-Arm 30,3\% betrug. Ein ähnliches Studiendesign war der NeoALTTO-Studie zugrunde gelegt [18]. Allerdings gab es hier einen zusätzlichen Arm mit einer HER2-Doppelblockade (Lapatinib zusammen mit Trastuzumab). Die pCR-Raten für die Kombinationsbehandlung $(\mathrm{L}+\mathrm{T})$ und die Einzelbehandlungen $\mathrm{T}$ und $\mathrm{L}$ waren jeweils $51,3,29,5$ und $24,7 \%$.

Die erst kürzlich vorgestellte NSABP B-41-Studie ist im Design der NeoALLTO-Studie sehr ähnlich [19]. Insgesamt wurden 529 Patientinnen eingeschlossen und erhielten AC, gefolgt von weekly Paclitaxel. 
tion of one year. The primary aim of the study was to determine the rate of pathological complete response (PCR) in relation to the type of targeted therapy. The pCR rates in this study for $L+T, T$ and $L$ respectively were: $62,52.5$ and $53.2 \%$. These differences were not statistically significant. Patients with a hormone receptor-negative breast cancer who received $\mathrm{L}+\mathrm{T}$ showed the highest pCR rate in the trend ( $\mathrm{L}+\mathrm{T}: 73 \%$ ).

As expected, grade 3 and 4 toxicities occurred more frequently under lapatinib ( $\mathrm{L}$ or $\mathrm{L}+\mathrm{T}$ ). In particular, grade 3 diarrhoeas were observed more frequently $(20 \%[\mathrm{~L}]$ or $27 \%[\mathrm{~L}+\mathrm{T}]$ vs. $2 \%[\mathrm{~T}])$. On the other hand, there were no differences with regard to cardiotoxicity or neutropenia in all three treatment groups. Therapy could be completed per protocol among $78 \%$ of those assigned to trastuzumab but only among $68 \%$ of those receiving lapatinib and among $63 \%$ of those receiving both targeted treatments.

\section{Gene Signature for Identifying Patients with HER2-positive Breast Cancer with High Probability of Developing Brain Metastases \\ $\nabla$}

It has long been known that HER2-positive patients have a higher likelihood of developing brain metastases. Treating these patients poses a particular challenge, not only because of the short survival time of these patients, but also because of a significantly restricted quality of life [20]. A better understanding of the molecular background of the mechanisms of brain metastasis could help in the development of new treatment strategies or treatment algorithms. One study has in fact reported that genes from the HER2 signal transduction pathway and DNA repair genes can help [21]. The time interval until onset of brain metastasis was 54 months in a group identified with a high-risk gene signature vs. 86 months in the low-risk group ( $p=0.038)$. Among those in the high-risk group who were hormone receptor negative, the time interval until onset of brain metastases was shorter still, at 41 months. The gene signature includes, among others, genes from the region of double-strand break repair mechanisms, such as RAD 51 for instance, which can be modified with new, innovative therapies. Accordingly, these insights ought to be considered when developing study designs for the prevention of brain metastases.

\section{mTOR Inhibition in Metastatic, HER2-negative Breast Cancer}

$\nabla$

Significant advances have also been made in the last year in the treatment of HER2-negative breast cancer. A better understanding of the signal cascades in breast cancer could help identify new targets in breast cancer [22]. Focus in this instance was on the PI3K and MAPK signal pathways. One molecule from these signal pathways that has already been tested in metastatic breast cancer is mTOR, which can be inhibited with everolimus. In the prospective, randomized phase III study BOLERO-2, postmenopausal women with hormone-receptor-positive, HER2-negative breast cancer were treated, after progress following nonsteroidal aromatase inhibition therapy, with the combination of exemestane and everolimus, and a significant advantage in the combination of exemestane and everolimus versus aromatase-inhibition therapy alone was demonstrated [23]. In the latest update after 18-month follow-up, a significant advantage in progression-free survival was observed, at an HR of 0.38 (95\% CI: $0.31-0.48$,
Unter weekly Paclitaxel unterschieden sich die 3 Behandlungsarme hinsichtlich des HER2-zielgerichteten Therapiekonzepts. Die Patientinnen erhielten entweder Lapatinib (L), Trastuzumab $(\mathrm{T})$ oder beides $(L+T)$. Nach erfolgter Operation wurde die zielgerichtete Therapie mit Trastuzumab für die Dauer von insgesamt einem Jahr fortgesetzt. Primäres Studienziel war die Rate der pathologischen Komplettremissionen ( $\mathrm{pCR}$ ) in Abhängigkeit von der Art der zielgerichteten Therapie. Die pCR-Raten in dieser Studie waren für die Therapien L+T, T und L: 62, 52,5 und 53,2\%. Diese Unterschiede waren statistisch nicht signifikant. Patientinnen mit einem hormonrezeptornegativen Mammakarzinom mit $\mathrm{L}+\mathrm{T}$ wiesen tendenziell die höchste $\mathrm{pCR}-$ Rate (L+T: 73\%) auf.

Unter Lapatinib (L oder $\mathrm{L}+\mathrm{T}$ ) traten erwartungsgemäß deutlich häufiger Grad-3- und -4-Toxizitäten auf. Insbesondere wurden Grad-3Diarrhöen häufiger beobachtet (20\% [L] bzw. $27 \%$ [L+T] vs. $2 \%[T]$ ). Hingegen gab es keine Unterschiede hinsichtlich Kardiotoxizität und Neutropenie in allen 3 Behandlungsgruppen. Die protokollgerechte Therapie konnte bei $78 \%$ mit Trastuzumab-Gabe aber nur bei $68 \%$ mit Lapatinib bzw. bei $63 \%$ mit beiden zielgerichteten Therapien verabreicht werden.

\section{Gensignatur zur Identifikation von Patientinnen mit einem HER2-positiven Mammakarzinom mit hoher Wahrscheinlichkeit für die Entwicklung von Hirnfiliae $\nabla$}

Schon seit einiger Zeit ist bekannt, dass HER2-positive Patientinnen eine höhere Wahrscheinlichkeit haben, Gehirnmetastasen zu entwickeln. Die Behandlung dieser Patientinnen stellt eine besondere Herausforderung dar, nicht nur wegen der kurzen Überlebenszeit dieser Patientinnen, sondern auch wegen einer deutlich eingeschränkten Lebensqualität [20]. Mehr über die molekularen Hintergründe der Mechanismen der Hirnmetastasierung könnte helfen, um neue Behandlungswege oder Therapiealgorithmen zu entwickeln. Tatsächlich wurde in einer Studie berichtet, dass Gene aus dem HER2-Signaltransduktionweg und DNA-Reparaturgene helfen können [21]. Das Zeitintervall bis zum Auftreten von Hirnfiliae betrug 54 Monate einer durch diese Gene festgelegte High-Risk-SignaturGruppe vs. 86 Monate in der Low-Risk-Gruppe ( $=0,038)$. Bei Hormonrezeptornegativität verkürzte sich in der High-Risk-Gruppe das Zeitintervall bis zum Auftreten von Hirnfiliae zusätzlich auf 41 Monate. Ein Bestandteil der Gensignatur sind Gene u.a. aus dem Bereich der Doppelstrangreparaturmechanismen, wie z.B. RAD 51, die sich therapeutisch mit neuen innovativen Therapien modifizieren lassen. Aus diesem Grund sollten diese Erkenntnisse bei der Konzeption von Studiendesigns zur Prävention von Hirnfiliae entsprechend berücksichtigt werden.

\section{mTOR-Inhibition bei metastasiertem,}

\section{HER2-negativem Brustkrebs}

$\nabla$

Auch beim HER2-negativen Mammakarzinom konnte im letzten Jahr ein bedeutsamer Fortschritt bei der Behandlung erzielt werden. Das bessere Verständnis der Signalkaskaden beim Mammakarzinom konnte helfen, neue Targets beim Mammakarzinom zu identifizieren [22]. Im Fokus waren hier insbesondere der PI3K- und MAPK-Signalweg. Ein Molekül aus diesen Signalwegen, welchen nun bereits beim metastasierten Mammakarzinom geestet ist, ist mTOR, welches mit Everolimus inhibiert werden kann. In der prospektiv randomisierten Phase-III-Studie BOLERO-2 wurden postmenopausale Patientinnen 


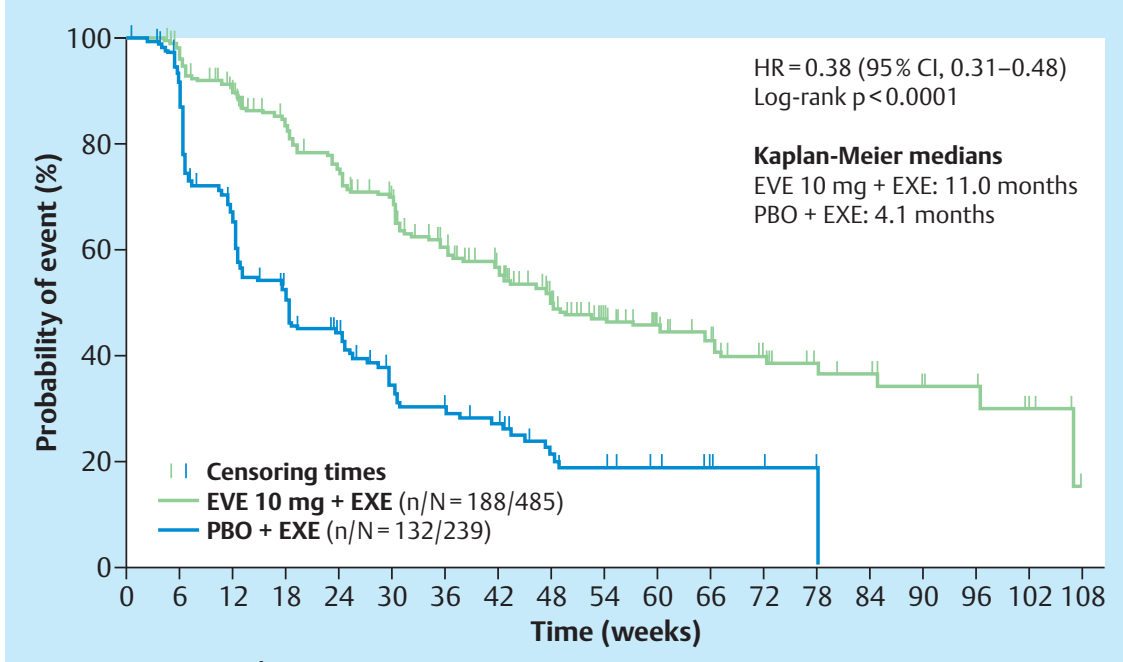

Fig. 4 Progression-free survival probability in the BOLERO-2 study (adapted from [24]) (HR: hazard ratio, $\mathrm{Cl}$ : confidence interval, EVE: everolimus, EXE: exemestan, PBO: placebo).

Patients at risk

$\begin{array}{lllllllllllllllllll}485 & 427 & 359 & 292 & 239 & 211 & 166 & 140 & 108 & 77 & 62 & 48 & 32 & 21 & 18 & 11 & 10 & 5 & 0\end{array}$

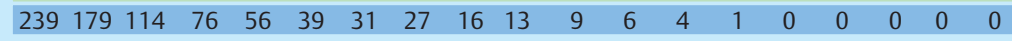

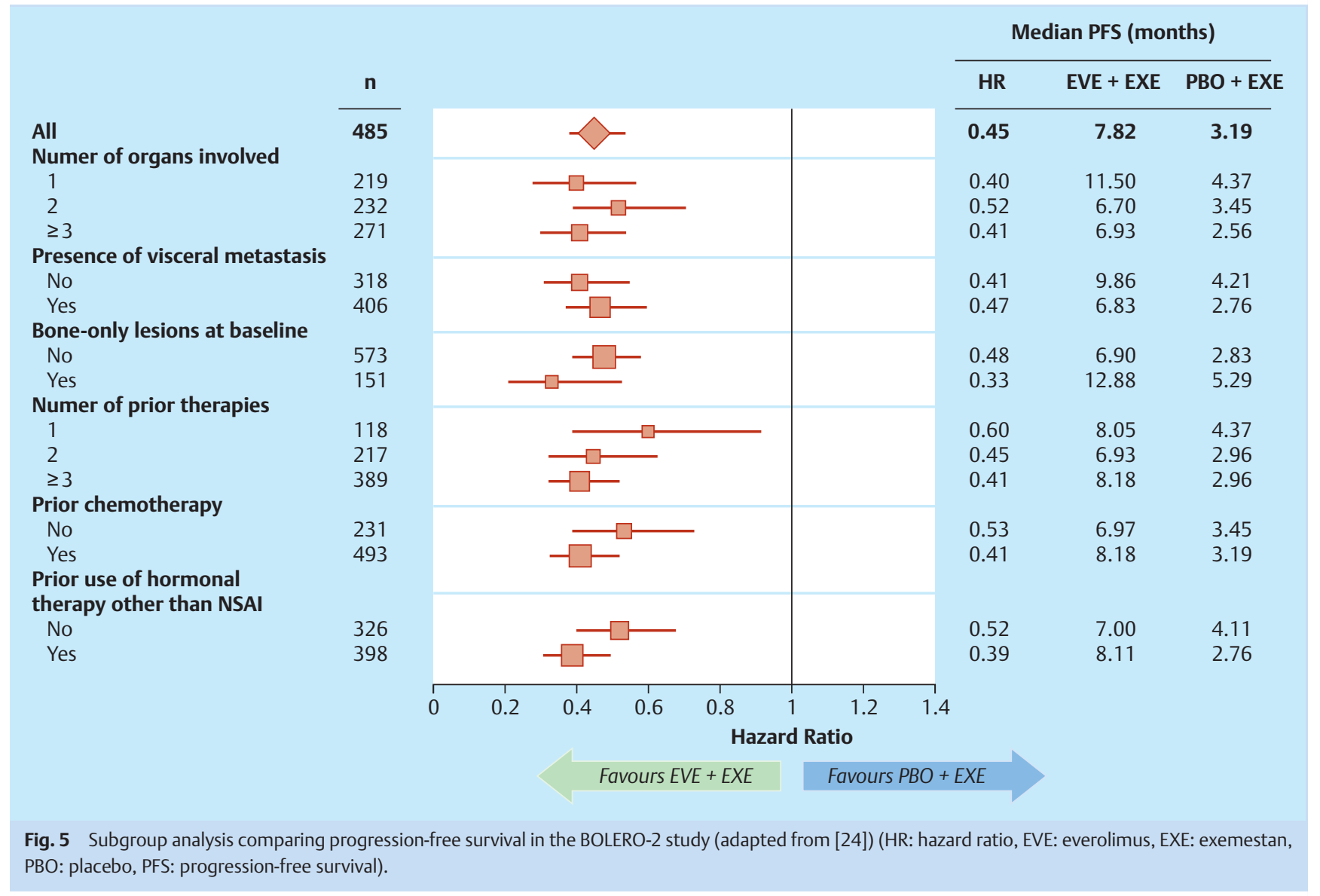

$\mathrm{p}<0.0001$ ) [24]. The difference was 11 vs. 4.1 months in favour of the combination arm with everolimus ( $\bullet$ Fig. 4). This advantage was consistent across all subgroups, irrespective of age, prior therapies, or presence of bone or other visceral metastases ( Fig. 5). Additionally, the benefit associated with this therapy was associated with a longer preservation of quality of life [25]. mit einem hormonrezeptorpositiven, HER2-negativen Mammakarzinom nach einem Progress nach einer nicht steroidalen Aromatasehemmertherapie mit der Kombination aus Exemestan und Everolimus behandelt und es konnte ein signifikanter Vorteil für die Kombination von Exemestan und Everolimus im Vergleich zu einer alleinigen Aromatasehemmertherapie nachgewiesen werden [23]. Im neu- 


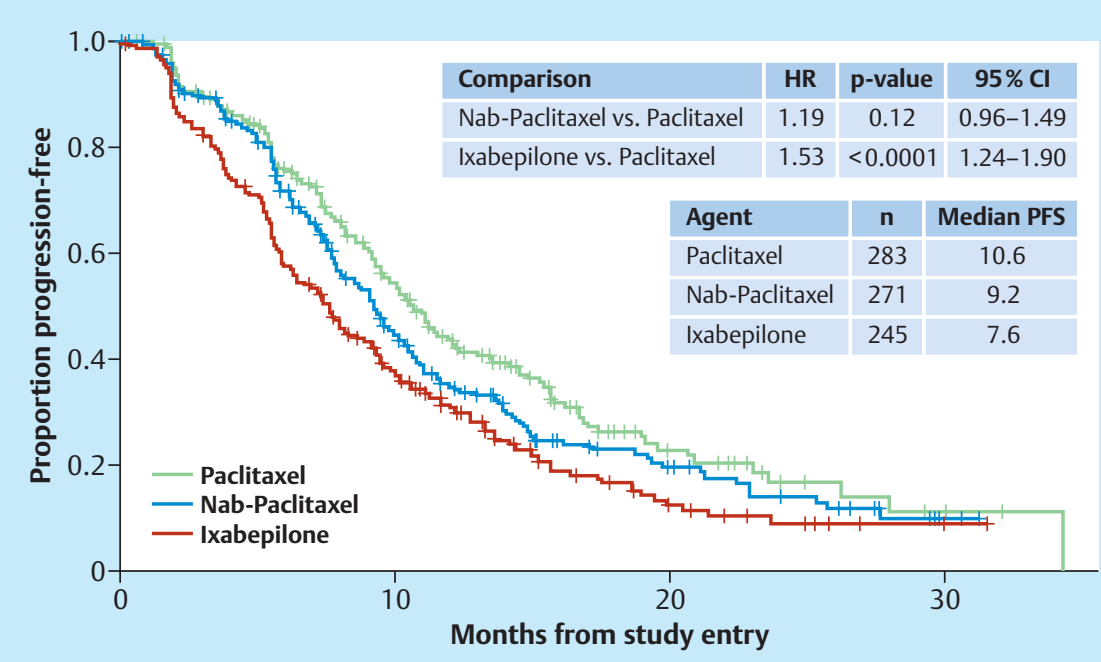

Fig. 6 Progression-free survival with nab-paclitaxel or ixabepilone compared to paclitaxel (adapted from [33]) (HR: hazard ratio, PFS: progression-free survival).

Further analysis of this collective of studies has revealed how this benefit relates to age. The significant improvement was also observed in both subgroups ( $<65$ years, $\geq 65$ years); $(<65$ years: HR $0.38, \geq 65$ years: HR 0.59) [26]. An interesting question in this collective is the evaluation of this new substance in relation to bone metastases. A clear delay in progression of the disease was observed in combination with everolimus [27].

\section{Breast cancer-specific mutations and signal pathways}

In "The Cancer Genome Atlas" (TCGA), a series of different cohorts of cancer patients is being studied comprehensively and genomewide for the various levels of systems biology. The first article relating to breast cancer from this project was just recently published [6]. The entire exome of over 500 tumours was sequenced, and it was studied whether somatic mutations against the reference genome are involved in the pathogenesis of breast cancer. In this study design, with the number of cases and bioinformatics tools used, 35 genes were described whose mutations play an as yet uncharacterized role in most breast cancer cases. Nevertheless, the signals of genes TP53 and PI3K (phosphatidylinositol-3kinase) are so frequent and conspicuous that they can be observed at a relevant frequency in all subtypes of breast cancer [6]. While the TCGA can currently make no statements on the implications for prognoses or therapy, it is already being studied in clinical trials whether mutations in these genes, in particular the PI3K gene and the signal pathway involved, play a role in prognosis and the efficacy of PI3K inhibitors. All studies published so far still have a very small number of cases and the results are suggestive at best. It has been shown, for instance, that a mutation in PI3KCA was associated with a poorer prognosis among patients receiving PI3K inhibition as monotherapy, while it was associated with a better prognosis among combination treatments with anti-hormonal therapy or chemotherapy [28]. In the FinHer study, somatic gene mutations in PI3K were also compared with prognosis and therapy response-related treatment status, however no correlation with prognosis or trastuzumab efficacy was observed [29]. Somatic mutations were also sequenced in several neoadjuvant studies involving aromatase inhibitors $[8,30]$. There are initial indications that mutations may have different implications for the efficacy of treatment with an aromatase inhibitor [8]. esten Update mit 18 Monaten Follow-up zeigte sich ein signifikanter Vorteil im progressionsfreien Überleben dieser Kombination mit einer HR von 0,38 (95\%-KI: 0,31-0,48, p<0,0001) [24]. Der Unterschied betrug 11 vs. 4,1 Monate zugunsten des Kombinationsarms mit Everolimus ( $\bullet$ Abb. 4). Dieser Vorteil zeigte sich konsistent in allen Subgruppen unabhängig vom Alter, den Vortherapien oder ob Knochen bzw. zusätzlich viszerale Metastasen vorlagen ( $\bullet$ Abb.5). Der mit der Therapie verbundene Benefit war zusätzlich mit einem längeren Erhalt der Lebensqualität verbunden [25]. In einer weiteren Analyse dieses Studienkollektivs wurde ausgewertet, wie sich dieser Benefit in Abhängigkeit vom Alter verhält. In beiden Subgruppen ( $<65$ Jahre, $\geq 65$ Jahre) konnte die signifikante Verbesserung ebenfalls beobachtet werden ( $<65$ Jahre - HR 0,38, $\geq 65$ Jahre - HR 0,59) [26]. Eine interessante Fragestellung in diesem Kollektiv ist die Beurteilung dieser neuen Substanz in Bezug auf Knochenmetastasen. Hierbei zeigte sich in der Kombination mit Everolimus eine deutliche Verzögerung der Progression der Erkrankung [27].

\section{Brustkrebsspezifische Mutationen und Signalwege}

In „The Cancer Genome Atlas“ (TCGA) wird eine Reihe von verschiedenen Kohorten von Karzinompatienten umfassend und genomweit für die verschiedenen Ebenen der Systembiologie untersucht. Erst kürzlich ist die erste Publikation dieses Projekts in Bezug auf das Mammakarzinom veröffentlicht worden [6]. An über 500 Tumoren wurde das komplette Exom sequenziert und es wurde untersucht, ob somatische Mutation im Vergleich zum Referenzgenom an der Pathogenese des Mammakarzinoms beteiligt ist. In diesem Studiendesign, mit dieser Fallzahl und den verwendeten bioinformatischen Werkzeugen sind 35 Gene beschrieben worden, deren Mutationen beim Mammakarzinom eine in den meisten Fällen noch nicht näher charakterisierte Rolle spielen. Jedoch waren die Signale der Gene TP53 und PI3K (Phosphatidylinositol-3-Kinase) so häufig und auffällig, dass sie bei allen Subtypen des Mammakarzinoms in einer relevanten Häufigkeit gesehen werden konnten [6].

Während der TCGA momentan noch keine Aussagen über Prognose oder Therapieimplikationen machen kann, wird in klinischen Studien bereits untersucht, ob Mutationen in diesen Genen, insbesondere dem PI3K-Gen und dem beteiligten Signalweg, eine Rolle bei der Prognose und der Effektivität von PI3K-Inhibitoren spielen. Alle bislang publizierten Studien haben noch eine sehr kleine Fallzahl und die Ergebnisse können höchstens suggestiv sein. Es konnte z.B. gezeigt werden, dass die Mutation in PI3KCA mit einer schlechteren 
Overall, it can be stated that the analysis of somatic mutations offers meaningful additional information for a molecular understanding of pathogenesis and progression of breast cancer. Initial insights imply that the PI3K signal pathway is of great interest for a better understanding of tumour biology, and that its inhibitors could be of clinical relevance in certain subtypes. Since mutations can accumulate in the course of cancer progression [31], it is probable that biopsies of the metastases would be necessary for a detailed study of these mechanisms. To what extent circulating tumour cells could help in this context is currently the object of ongoing research [32].

\section{Chemotherapy in the Adjuvant Setting \\ $\nabla$}

Despite its adverse effects, chemotherapy remains one of the central pillars of systemic treatment, at least for a majority of patients. Numerous studies have been performed in recent years regarding the dosage and sequence, which have resulted in rules and guidelines [3-5, 22,33]. Studies in the past year have also revealed new insights. In the GEICAM-2003-02 study [34], 6 cycles of FAC $\mathrm{q} 3 \mathrm{w}$ were compared with the conventional dose of 4 cycles FAC, followed by 8 doses of paclitaxel $100 \mathrm{mg} / \mathrm{m}^{2}$ weekly in node-negative patients. Similarly to an earlier GEICAM study with docetaxel, recurrence-free survival was significantly better in the taxane arm in this study as well ( $p=0.043$ ), while the hazard ratio was also comparable. The study therefore confirms the current AGO recommendation for anthracycline-based and taxane-based chemotherapy for node-negative and positive patients.

In close to 5000 node-positive patients, the NSABP B-38 study [35] compared 6 cycles of TAC with 2 dose-dense regimens: 4 cycles of $\mathrm{AC} \mathrm{q} 2 \mathrm{w}$ followed by 4 cycles of paclitaxel $\mathrm{q} 2 \mathrm{w}$, or 4 cycles of AC q2w followed by 4 cycles of paclitaxel-gemcitabine q2w. No differences in recurrence-free survival were observed between the 3 therapy arms, and at best a statistical trend suggesting superiority of the dose-dense AC-P over TAC regimens $(p=0.07)$. It makes no sense, however, to make a comparison with the German ETC study in terms of either the risk group or the chemotherapy.

\section{Chemotherapy in the Metastatic Setting \\ $\nabla$}

Although metastatic patients are the first to receive modern therapies and molecular tests, chemotherapy still remains the standard treatment in most cases, at least at some point in the course of therapy. Nevertheless, the number of studies testing the additional action of a targeted treatment in conjunction with standard therapy such as chemotherapy is increasing. Also being tested are new modes of application of the chemotherapeutic molecules, such as lysosomal application modes. For instance, in 799 locally recurrent or metastasized breast cancer patients, the CALGB 40502 trial compared the first-line administration of paclitaxel $90 \mathrm{mg} / \mathrm{m}^{2} \mathrm{q} 1 \mathrm{w}$ with nab-paclitaxel $150 \mathrm{mg} / \mathrm{m}^{2} \mathrm{q} 1 \mathrm{w}$ and ixabepilone $16 \mathrm{mg} / \mathrm{m}^{2} \mathrm{q} 1 \mathrm{w}$ (not approved in Germany), each in combination with bevacizumab $10 \mathrm{mg} / \mathrm{kg}$ q2w [36]. Restaging took place after every 2 cycles with 6 doses and a pause in week 4. In each case of response to therapy or stability, treatment was either continued until progression or chemotherapy discontinued and bevacizumab continued as maintenance treatment. Neither nab-paclitaxel nor ixabepilone exhibited an improvement in
Prognose bei Patientinnen mit einer PI3K-Inhibition als Monotherapie, aber mit einer besseren Prognose bei Kombinationsbehandlungen mit Antihormontherapie oder Chemotherapie verbunden war [28]. In der FinHER-Studie wurden auch somatische Genmutationen in PI3K mit der Prognose und dem Therapieansprechen entsprechend dem Trasuzumab-Behandlungsstatus verglichen, jedoch konnte kein Zusammenhang mit der Prognose oder der Trastuzumab-Wirksamkeit gesehen werden [29]. Auch in mehreren neoadjuvanten Studien mit Aromatasehemmern wurden somatische Mutationen durch Sequenzierung bestimmt $[8,30]$. Es gibt erste Hinweise, dass die Mutationen unterschiedliche Implikationen für die Wirksamkeit einer Therapie mit einem Aromatasehemmer haben könnten [8].

Insgesamt kann festgehalten werden, dass die Analyse von somatischen Mutationen eine bedeutsame zusätzliche Information für das molekulare Verständnis der Pathogenese und Progression des Mammakarzinoms bietet. Erste Einblicke implizieren, dass der PI3K-Signalweg für ein besseres Verständnis der Tumorbiologie hochinteressant ist und seine Inhibitoren eine klinische Relevanz in einzelnen Subtypen vermuten lassen. Da sich Mutationen im Laufe der Progression eines Karzinoms anhäufen können [31], werden für eine detaillierte Untersuchung dieser Mechanismen wahrscheinlich Biopsien der Metastasen notwendig werden. Inwieweit hierbei zirkulierende Tumorzellen helfen können, ist momentan Bestandteil wissenschaftlicher Bestrebungen [32].

\section{Chemotherapie in der adjuvanten Situation \\ $\nabla$}

Die Chemotherapie ist trotz ihrer Nebenwirkungen immer noch die zentrale Säule der systemischen Behandlung, zumindest für einen großen Teil der Patientinnen. Zur Fragestellung der Dosierung und Sequenz wurden in den vergangenen Jahren zahlreiche Studien durchgeführt, die sich in Leit- und Richtlinien niedergeschlagen haben [3-5,22,33]. Auch im letzten Jahr gab es Erkenntnisse aus neuen Studien. In der GEICAM-2003-02-Studie [34] wurden in der adjuvanten Situation 6 Zyklen FAC q3w in der konventionellen Dosierung mit 4 Zyklen FAC, gefolgt von 8 Gaben Paclitaxel $100 \mathrm{mg} / \mathrm{m}^{2}$ wöchentlich bei nodalnegativen Patientinnen verglichen. Ähnlich wie bereits in einer früheren GEICAM-Studie mit Docetaxel war auch in dieser Studie der Taxan-Arm beim rezidivfreien Überleben signifikant überlegen ( $p=0,043)$, die Hazard Ratio war ebenfalls vergleichbar. Die Studie bestätigt damit die aktuelle AGO-Empfehlung einer anthrazyklinund taxanhaltigen Chemotherapie bei nodalnegativen und -positiven Patientinnen.

In der NSABP-B-38-Studie [35] wurden bei knapp 5000 nodalpositiven Patientinnen 6 Zyklen TAC mit 2 dosisdichten Schemata verglichen: 4 Zyklen AC q2w, gefolgt von 4 Zyklen Paclitaxel q2w, oder 4 Zyklen AC q2w, gefolgt von 4 Zyklen Paclitaxel-Gemcitabin q2w. Im rezidivfreien Überleben fand sich kein Unterschied zwischen den 3 Therapiearmen, allenfalls ein statistischer Trend einer Überlegenheit des dosisdichten AC-P gegenüber TAC-Regimes $(p=0,07)$. Ein Vergleich zur deutschen ETC-Studie ist allerdings weder bezüglich des Risikokollektivs noch hinsichtlich der Chemotherapie sinnvoll.

\section{Chemotherapie in der metastasierten Situation $\nabla$}

Auch wenn Patientinnen in der metastasierten Situation die ersten sind, bei denen moderne Therapien und molekulare Tests angewendet werden, bleibt die Chemotherapie doch meistens die Standardtherapie, zumindest zu einem Zeitpunkt im Therapieverlauf. Jedoch nehmen die Studien deutlich zu, welche die zusätzliche Wirkung 
progression-free survival (PFS) or overall survival (OS) at this dose among a chemotherapy-naïve patient group compared to the standard therapy with paclitaxel (PFS: Nab vs. Pac HR 1.19, $\mathrm{p}=0.12$, 95\% CI: 0.96-1.49; Ixa vs. Pac HR 1.53, p<0.0001, 95\% CI: 1.24-1.90; OS: Nab vs. Pac HR 1.02, p=0.92, CI: 0.75-1.38; Ixa vs. Pac HR 1.28, p = 0.10, 95\% CI: 0.95-1.72). Furthermore, a significantly stronger haematological toxicity was observed under nab-paclitaxel, at 51 vs. $21 \%$ with paclitaxel $(\mathrm{p}<0.0001)$. In both experimental arms, grade $3 / 4$ sensory neuropathy occurred significantly more frequently compared to paclitaxel (Nab 25\%, p = 0.012 vs. Ixa 25\%, p= 0.022 vs. Pac 16\%). ๑ Fig. 6 shows the Kaplan-Meier curves of the study. Also, therapy was discontinued more frequently under nab-paclitaxel and ixabepilone than under paclitaxel. In $45 \%$ of patients, the dose had already been reduced by cycle 3 , compared to $15 \%$ under paclitaxel. In the CALGB 40502 study, neither nab-paclitaxel nor ixabepilone showed an improvement over paclitaxel. According to a current meta-analysis of randomized controlled studies of metastatic breast cancer, longer progression-free survival can be achieved by a longer duration of therapy, albeit with increased toxicity [37]. In this context, the degree of higher toxicity of nab-paclitaxel at weekly doses of $150 \mathrm{mg} / \mathrm{m}^{2}$ becomes more important in comparison to paclitaxel.

\section{Health Economics}

$\nabla$

We are being confronted with an increasing number of healtheconomic terms, such as the German AMNOG, IQWiG and GBA, which are now a fixed part of global therapy planning [38]. The effects of such concepts extend beyond Germany's borders; they are shaping oncology in other countries as well, as evidenced in international data. A search for the term "costs" on the ASCO Virtual Meeting portal, for instance, delivers 1460 hits for this year's meeting alone - including some highly interesting articles on breast cancer.

Internationally, cost-utility models are still based on calculating QALYs (quality-adjusted life years), i.e. the costs required to gain one additional year of life at $100 \%$ quality of life.

The current data on the ABCSG-12 [39] and ZO-FAST [40] studies have rekindled the debate on bisphosphonates for preventing metastases [41]. Regarding the cost-effectiveness of zoledronic acid in the adjuvant setting of the premenopausal woman, a German cost model has already been published [39] stating that its use at $-€ 45.83$ per QALY represents a cost-effective therapy option for premenopausal women with hormone receptor-positive $(\mathrm{HR}+)$ breast cancer. A current work calculated the cost-effectiveness of zoledronic acid based on the ZO-FAST trial results [42]. In the basic model, a gain of 1.61 life years, 2.06 disease-free life years and 0.93 QALYs were calculated at a cost of $\$ 7,436$. At (consequently) \$7967 per QALY, the early use of zoledronic acid ( $4 \mathrm{mg}, \mathrm{q} 6 \mathrm{~m}$ ) is indeed a cost-effective therapy option even for postmenopausal women - The American healthcare system already deems that clear cost-effectiveness exists for all costs per QALY $<\$ 50000$ and debatable cost-effectiveness exists at costs of \$50000-\$100000 per QALY.

Radiotherapy among elderly patients is likewise undergoing scrutiny, even with good prognostic criteria. A randomized phase III trial studied the utility of radiotherapy plus tamoxifen versus tamoxifen alone in patients $\geq 70$ years, cN0, T1, status after BET and HR+ [43]. No significant difference was observed in relation to disease-free survival and overall survival. According to current einer zielgerichteten (targeted) Therapie zusätzlich zu einer Standardtherapie wie der Chemotherapie testen. Auch werden neue Applikationsformen der chemotherapeutischen Moleküle wie lysosomale Applikationsformen getestet. In der CALGB-40502-Studie wurde z. B. bei 799 lokal rezidivierten oder metastasierten Mammakarzinompatientinnen in der First-Line die Gabe von Paclitaxel $90 \mathrm{mg} / \mathrm{m}^{2}$ q1w im Vergleich zu Nab-Paclitaxel $150 \mathrm{mg} / \mathrm{m}^{2}$ q1w sowie Ixabepilone $16 \mathrm{mg} / \mathrm{m}^{2} \mathrm{q} 1 \mathrm{w}$ (in Deutschland nicht zugelassen), jeweils in Kombination mit Bevacizumab $10 \mathrm{mg} / \mathrm{kg}$ q2w, verglichen eingesetzt wurde [36]. Ein Re-Staging erfolgte nach jeweils 2 Zyklen mit 6 Gaben und Pause in Woche 4. Bei Therapieansprechen bzw. stabiler Situation wurde entweder die Therapie bis zur Progression fortgesetzt oder die Chemotherapie beendet und Bevacizumab als Erhaltungstherapie fortgeführt. Weder Nab-Paclitaxel noch Ixabepilone haben in diesen Dosierungen bei einem Chemotherapie-naiven Patientinnenkollektiv eine Verbesserung im progressionsfreien Überleben (PFS) oder Gesamtüberleben (OS) im Vergleich zum Standard mit Paclitaxel zeigen können (PFS: Nab vs. Pac HR 1,19, p=0,12, 95\%-KI: 0,96-1,49; Ixa vs. Pac HR 1,53, p<0,0001, 95\%-KI: 1,24-1,90; OS: Nab vs. Pac HR 1,02, p=0,92, KI: 0,75-1,38; Ixa vs. Pac HR 1,28, $\mathrm{p}=0,10,95 \%-K I: 0,95-1,72)$. Zudem zeigte sich unter Nab-Paclitaxel eine signifikant stärkere Hämatotoxizität mit 51 vs. $21 \%$ bei Paclitaxel ( $p<0,0001$ ). In beiden experimentellen Armen trat signifikant häufiger eine sensorische Neuropathie Grad 3/4 im Vergleich zu Paclitaxel auf (Nab 25\%, p = 0,012 vs. Ixa 25\%, p = 0,022 vs. Pac $16 \%$ ). Die KaplanMeier-Kurven der Studie sind in $\bigcirc$ Abb. 6 dargestellt. Auch Therapieabbrüche wurden unter Nab-Paclitaxel und Ixabepilone deutlich häufiger als unter Paclitaxel angegeben. In Zyklus 3 war bei Nab-Paclitaxel bereits bei $45 \%$ der Patientinnen eine Dosisreduktion im Vergleich zu 15\% unter Paclitaxel erfolgt.

In der CALGB-40502-Studie haben weder Nab-Paclitaxel noch Ixabepilone eine Verbesserung gegenüber Paclitaxel zeigen können. Mit einer längeren Therapiedauer kann gemäß einer aktuellen Metaanalyse von randomisiert-kontrollierten Studien beim metastasierten Mammakarzinom ein längeres progressionsfreies Überleben bei allerdings zunehmender Toxizität erreichen werden [37]. In diesem Kontext gewinnt das Ausmaß einer höheren Toxizität von Nab-Paclitaxel in der wöchentlichen Dosierung mit $150 \mathrm{mg} / \mathrm{m}^{2}$ im Vergleich zu Paclitaxel an Bedeutung.

\section{Gesundheitsökonomie}

$\nabla$

Mit den Begriffen AMNOG, IQWiG, GBA werden wir mehr und mehr mit gesundheitsökonomischen Themen konfrontiert und sind Bestandteil der globalen Therapieplanung [38]. Dieses ist jedoch keine allein nationale Problematik, sondern prägt auch international mehr und mehr die Onkologie, wie internationale Daten zeigen. So liefert eine Suche zu dem Begriff „costs“ auf der ASCO-Virtual-MeetingHomepage zum diesjährigen Kongress allein 1460 Treffer - hierunter zeigen sich auch einige sehr interessante Beiträge zum Thema Mammakarzinom.

International basieren Kosten-Nutzwert-Analysen weiterhin auf der Berechnung der QALYs (qualitätsadjustierte Lebensjahre), d. h. welche Kosten sind notwendig, um ein zusätzliches Lebensjahr bei $100 \%$ iger Lebensqualität zu gewinnen.

Die aktuellen Daten zur ABCSG-12- [39] und ZO-FAST-Studie [40] haben die Diskussion von Bisphosphonaten zur Prävention von Metastasen weiter angefacht [41]. In Bezug auf die Kosteneffektivität von Zoledronsäure in der adjuvanten Situation der prämenopausalen Frau wurde bereits ein deutsches Kostenmodell publiziert [39], welches gezeigt hat, dass der Einsatz mit $-45,83 €$ pro QALY eine kosten- 
recommendations from AGO Germany, following these criteria, radiotherapy can be omitted in individual cases (AGO 2b, B, \pm ) [44]. Health economics can help weigh up the pros and cons in this situation. A health-economic model was used to calculate the costs and utility for employing radiotherapy plus hormonal therapy vs. hormonal therapy alone for a group of 10000 women aged $\geq 70$ years with HR+- and T1 breast cancer [45]. The calculated incremental cost-effectiveness ratio (ICER) was \$923,017 per QALY. It is therefore not a cost-effective therapy. These factors should therefore be weighed when making shared decisions with patients.

In the metastatic setting, the costs are mostly higher than in the adjuvant setting, due both to the use of modern treatments and to the treatment of symptoms and adverse effects [46]. Oncologists in Germany are currently debating the use of bevacizumab and eribulin in metastatic settings. Refaat et al. compared the combination of paclitaxel and bevacizumab vs. paclitaxel alone in a Markov model based on data from the E2100 trial [47]. 0.369 QALYs were achieved with the addition of bevacizumab. In terms of costs, this equated to $\$ 232720.72$ per QALY. The authors concluded that, from an American perspective, this is not a costeffective option.

According to the EMBRACE (phase III) study [48], use of eribulin versus TPC (treatment of physician's choice) achieved a significant prolongation of overall survival of 2.5 months (HR 0.81; $\mathrm{p}=0.041$ ). The cost-effectiveness of eribulin versus the various alternative therapies was examined in a health-economic model [49]. Compared to TPC, eribulin added 0.208 life years and 0.119 QALYs. Given the costs of the drug, however, the ICER was $\$ 201790$ per QALY. This was due mostly to the low drug costs for vinorelbine and gemcitabine. In health-economics, there are continuing debates as to whether the costs of generic drugs or the original price upon market introduction for the therapy of comparison should be used for evaluating a new product. The authors therefore calculated the cost-effectiveness in comparison to ixabepilone (\$85130), liposomal doxorubicin (\$98538), nabpaclitaxel (\$119029) and capecitabine (\$154591), and concluded a possible cost-effectiveness for eribulin depending on setting and prior treatment.

The studies mentioned and their results make it clear that health-economic models, in particular in the context of current debates, could help in weighing up the advantages and disadvantages of various therapy options, and shed light on these options from another perspective - for both the adjuvant and the palliative setting in breast cancer patients.

\section{Conflict of Interest}

\section{$\nabla$}

This review was put together as decided in a planning discussion supported by Novartis Deutschland GmbH.

\footnotetext{
Affiliations

${ }^{1}$ Medizinische Klinik und Poliklinik II, Campus Charité Mitte, Berlin

2 Frauenklinik, Universitätsklinikum Erlangen, Erlangen

3 Department of Gynecology and Obstetrics, University Hospital Aachen

${ }^{4}$ Frauenklinik, Universitätsklinikum Heidelberg, Heidelberg

${ }^{5}$ Klinik für Senologie/Brustzentrum, Klinikum Essen-Mitte, Essen

${ }^{6}$ Department of Gynecology and Obstetrics, University Hospital Erlangen, Erlangen

7 Department of Obstetrics and Gynecology, University Tübingen, Tübingen

8 Frauenklinik, Klinikum der Universität Ulm, Ulm

${ }^{9}$ Klinik für Gynäkologie und Geburtshilfe, Marienhospital Bottrop, Bottrop
}

effektive Therapieoption für prämenopausale Frauen mit einem hormonrezeptorpositiven ( $\mathrm{HR}+)$ Mammakarzinom darstellt. In einer aktuellen Arbeit wurde die Kosteneffektivität von Zoledronsäure auf Basis der ZO-FAST-Studienergebnisse berechnet [42]. Im Basismodell wurde ein Gewinn von 1,61 Lebensjahren, 2,06 krankheitsfreien Lebensjahren und 0,93 QALYs bei Kosten von 7436\$ berechnet. Bei (somit) 7967 \$ pro QALY ist der frühe Einsatz von Zoledronsäure ( $4 \mathrm{mg}, \mathrm{q} 6 \mathrm{~m}$ ) auch für postmenopausale Frauen eine absolut kosteneffektive Therapieoption - im amerikanischen Gesundheitswesen wird von einer klaren Kosteneffektivität bei allen Kosten pro QALY von $<50000 \$$ und einer zu diskutierenden Kosteneffektivität bei Kosten von 50000-100000 \$ pro QALY ausgegangen.

Auch die Strahlentherapie der älteren Patientin steht aktuell bei sehr guten prognostischen Kriterien auf dem Prüfstand. Eine randomisierte Phase-III-Studie untersuchte den Vorteil einer Strahlentherapie plus Tamoxifen versus Tamoxifen alleine bei Patientinnen $\geq 70$ Jahre, cNO, T1, Zustand nach BET und HR+ [43]. Es zeigte sich kein signifikanter Unterschied in Bezug auf das krankheitsfreie Überleben und das Gesamtüberleben. Nach den aktuellen Empfehlungen der AGO kann bei diesen Kriterien ggf. individuell auf eine Radiatio verzichtet werden (AGO 2b, B, \pm ) [44]. Die Abwägung von Pro und Kontra kann die Gesundheitsökonomie an dieser Stelle unterstützen. Mittels eines gesundheitsökonomischen Modells wurden die Kosten und Vorteile für den Einsatz einer Radiatio plus Hormontherapie vs. nur Hormontherapie für ein Kollektiv von 10000 Frauen $\geq 70$ Jahre mit einem HR+- und T1-Mammakarzinom kalkuliert [45]. Es zeigte sich eine inkrementelle Kosteneffektivitätsratio (ICER) von 923017 \$ pro QALY. Es handelt sich somit um keine kosteneffektive Therapie. Diese Überlegungen sollten in eine gemeinsame Entscheidungsfindung mit der Patientin einfließen.

In der metastasierten Situation sind die Kosten sowohl aufgrund des Einsatzes von modernen Therapien als auch der Behandlung von Symptomen und Nebenwirkungen meist höher als in der Adjuvanz [46]. In Deutschland beschäftigt insbesondere die Diskussion um den Einsatz von Bevacizumab und Eribulin in der metastasierten Situation die onkologisch tätigen Ärztinnen und Ärzte. Refaat und Kollegen verglichen in einem Markov-Modell die Kombination von Paclitaxel und Bevacizumab vs. Paclitaxel alleine auf Basis der Daten der E2100-Studie [47]. Durch die Hinzunahme von Bevacizumab wurden 0,369 QALYs mehr erreicht. Unter Berücksichtigung der Kosten wurden 232720,72 \$ pro QALY kalkuliert. Die Autoren schlussfolgerten aus der amerikanischen Perspektive, dass es sich nicht um eine kosteneffektive Option handelt.

Entsprechend der EMBRACE-(Phase-III-)Studie [48] konnte der Einsatz von Eribulin im Vergleich zur TPC (treatment of physician's choice) eine signifikante Verlängerung des Gesamtüberlebens von 2,5 Monaten (HR 0,81; $p=0,041$ ) erzielen. In einem gesundheitsökonomischen Modell wurde nun die Kosteneffektivität von Eribulin im Vergleich zu den unterschiedlichen Alternativtherapien betrachtet [49]. Mit Eribulin konnten im Vergleich zur TPC 0,208 Lebensjahre und 0,119 QALYs gewonnen werden. Die ICER lag jedoch aufgrund der Medikamentenkosten bei 201790 \$ pro QALY. Diese bedingt sich insbesondere durch die niedrigen Medikamentenkosten für Vinorelbin und Gemcitabin. Es wird in der Gesundheitsökonomie weiterhin diskutiert, ob für die Bewertung eines neuen Produkts die Kosten der Generika oder des ursprünglichen Preises bei Markteintritt für die Vergleichstherapie verwendet werden sollten. Die Autoren berechneten deshalb auch die Kosteneffektivität im Vergleich zu Ixabepilon (85130 \$), liposomalem Doxorubicin (98538 \$), Nab-Paclitaxel (119029\$) und Capecitabin (154591\$), und schlussfolgerten eine mögliche Kosteneffektivität für Eribulin je nach Situation und Vortherapie. 


\section{References}

1 Strehl JD, Wachter DL, Fasching PA et al. Invasive breast cancer: recognition of molecular subtypes. Breast Care (Basel) 2011; 6: 258-264

2 Schmidt M, Fasching PA, Beckmann MW et al. Biomarkers in breast cancer - an update. Geburtsh Frauenheilk 2012; 72: 819-832

3 Fehm T, Janni W, Kummel S et al. Review: SABCS 2010-current treatment options for patients with breast cancer. Geburtsh Frauenheilk 2011; 71: 260-276

4 Kolberg HC, Luftner D, Lux MP et al. Breast cancer 2012-new aspects. Geburtsh Frauenheilk 2012; 72: 602-615

5 Kummel S, Kolberg HC, Luftner D et al. Breast cancer 2011-new aspects. Geburtsh Frauenheilk 2011; 71: 939-953

6 Cancer Genome Atlas Network. Comprehensive molecular portraits of human breast tumours. Nature 2012; 490: 61-70

7 Shah SP, Roth A, Goya R et al. The clonal and mutational evolution spectrum of primary triple-negative breast cancers. Nature 2012; 486: 395-399

8 Ellis MJ, Ding L, Shen $D$ et al. Whole-genome analysis informs breast cancer response to aromatase inhibition. Nature 2012; 486: 353-360

9 Fasching PA, Ekici AB, Adamietz BR et al. Breast cancer risk - genes, environment and clinics. Geburtsh Frauenheilk 2011; 71: 1056-1066

10 Paik S, Shak S, Tang G et al. A multigene assay to predict recurrence of tamoxifen-treated, node-negative breast cancer. N Engl J Med 2004; 351: 2817-2826

11 Badve S, Gray RJ, Baehner FL et al. Correlation between the DCIS Score and traditional clinicopathologic features in the prospectively designed E5194 clinical validation study. J Clin Oncol 2012; 30 (Suppl.): Abstr. 1005

12 McCormick B. RTOG 9804: A prospective randomized trial for "good risk" ductal carcinoma in situ (DCIS), comparing radiation (RT) to observation (OBS). J Clin Oncol 2012; 30 (Suppl.): Abstr. 1004

13 Gelmon KA, Boyle F, Kaufman B et al. Open-label phase III randomized controlled trial comparing taxane-based chemotherapy (Tax) with lapatinib (L) or trastuzumab (T) as first-line therapy for women with HER-2+ metastatic breast cancer: Interim analysis (IA) of NCIC CTG MA.31/GSK EGF 108919. J Clin Oncol 2012; 30: LBA671

14 Blackwell KL, Miles D, Gianni L et al. Primary results from EMILIA, a phase III study of trastuzumab emtansine (T-DM1) versus capecitabine (X) and lapatinib (L) in HER2-positive locally advanced or metastatic breast cancer $(\mathrm{MBC})$ previously treated with trastuzumab $(\mathrm{T})$ and a taxane. J Clin Oncol 2012; 30 (Suppl.): Abstr. LBA1

15 Verma S, Miles D, Gianni $L$ et al. Updated overall survival results from EMILIA, a phase 3 study of trastuzumab emtansine (T-DM1) vs. capecitabine and lapatinib in HER2-positive locally advanced or metastatic breast cancer. Ann Oncol 2012; 23 (Suppl. 9): ixe5

16 von Minckwitz G, Eidtmann $H$, Rezai $M$ et al. Neoadjuvant chemotherapy and bevacizumab for HER2-negative breast cancer. N Engl J Med 2012; 366: 299-309

17 Untch M, Loibl S, Bischoff J et al. Lapatinib versus trastuzumab in combination with neoadjuvant anthracycline-taxane-based chemotherapy (GeparQuinto, GBG 44): a randomised phase 3 trial. Lancet Oncol 2012; 13: 135-144

18 Baselga J, Bradbury I, Eidtmann $\mathrm{H}$ et al. Lapatinib with trastuzumab for HER2-positive early breast cancer (NeoALTTO): a randomised, openlabel, multicentre, phase 3 trial. Lancet 2012; 379: 633-640

19 Robidoux A, Tang G, Rastogi P et al. Evaluation of lapatinib as a component of neoadjuvant therapy for HER-2+ operable breast cancer: NSABP protocol B-41. J Clin Oncol 2012; 30 (Suppl.): Abstr. LBA506

20 Duchnowska R, Dziadziuszko R, Czartoryska-Arlukowicz B et al. Risk factors for brain relapse in HER2-positive metastatic breast cancer patients. Breast Cancer Res Treat 2009; 117: 297-303

21 Duchnowska R, Jassem J, Goswami CP et al. 13-gene signature to predict rapid development of brain metastases in patients with HER-2-positive advanced breast cancer. J Clin Oncol 2012; 30 (Suppl.): Abstr. 505

22 Liedtke C, Wolf MK, Kiesel L. New concepts for targeted systemic therapy in breast cancer. Geburtsh Frauenheilk 2010; 70: 625-633

23 Baselga J, Campone M, Piccart $M$ et al. Everolimus in postmenopausal hormone-receptor-positive advanced breast cancer. N Engl J Med 2012; 366: 520-529

24 Piccart M, Noguchi S, Pritchard KI et al. Everolimus for postmenopausal women with advanced breast cancer: updated results of the BOLERO-2 phase III trial. J Clin Oncol 2012; 30 (Suppl.): Abstr. 559
Die genannten Studien und ihre Ergebnisse verdeutlichen, dass gesundheitsökonomische Modelle insbesondere bei zeitgemäßen Diskussionen dabei unterstützen können, Vor- und Nachteile unterschiedlicher Therapieoptionen abzuwägen, und diese aus einer weiteren Perspektive zu beleuchten - sowohl für die adjuvante als auch für die palliative Situation bei Mammakarzinompatientinnen.

\section{Interessenkonflikt}

Diese Übersichtsarbeit ist nach einer von der Firma Novartis Deutschland $\mathrm{GmbH}$ unterstützten Planungsbesprechung zustande gekommen.

25 Beck J, Rugo HS, Burris HA et al. BOLERO-2: Health-related quality-oflife in metastatic breast cancer patients treated with everolimus and exemestane versus exemestane. J Clin Oncol 2012; 30 (Suppl.): Abstr. 539

26 Pritchard KI, Burris HA, Rugo HS et al. Safety of everolimus for women over 65 years of age with advanced breast cancer $(B C)$ : 12.5 -mo followup of BOLERO-2. J Clin Oncol 2012; 30 (Suppl.): Abstr. 551

27 Gnant M, Baselga J, Rugo HS et al. Effects of everolimus (EVE) on disease progression in bone and bone markers (BM) in patients (pts) with bone metastases (mets). J Clin Oncol 2012; 30 (Suppl.): Abstr. 512

28 Oliveira M, Navarro A, De Mattos-Arruda L et al. PI3K pathway (PI3Kp) dysregulation and response to pan-PI3K/AKT/mTOR/dual PI3K-mTOR inhibitors (PI3Kpi) in metastatic breast cancer (MBC) patients (pts). J Clin Oncol 2012; 30 (Suppl.): Abstr. 509

29 Loi S, Michiels S, Lambrechts D et al. Tumor PIK3CA mutations, lymphocyte infiltration, and recurrence-free survival (RFS) in early breast cancer (BC): results from the FinHER trial. J Clin Oncol 2012; 30 (Suppl.): Abstr. 507

30 Ellis MJ, Ding L, Shen $D$ et al. Whole genome sequencing to characterize luminal-type breast cancer. J Clin Oncol 2012; 30 (Suppl.): Abstr. 503

31 Yates LR, Campbell PJ. Evolution of the cancer genome. Nat Rev Genet 2012; 13: 795-806

32 Hartkopf $A D$, Banys $M$, Krawczyk $N$ et al. Circulating tumor cells in early-stage breast cancer. Geburtsh Frauenheilk 2011; 71: 1067-1072

33 Untch M, Gerber B, Mobus V et al. Zurich consensus: statement of German experts on St. Gallen conference 2011 on breast cancer (Zurich 2011). Geburtsh Frauenheilk 2011; 71: 381-390

34 Martin M, Lluch A, Ruiz A et al. Randomized phase III study of adjuvant chemotherapy for high-risk, node-negative breast cancer (BC) comparing FAC with FAC followed by weekly paclitaxel: First efficacy analysis of the GEICAM/2003-02 trial. J Clin Oncol 2012; 30 (Suppl.): Abstr. 1001

35 Swain SM, Tang G, Geyer CE et al. NSABP B-38: Definitive analysis of a randomized adjuvant trial comparing dose-dense (DD) AC $\rightarrow$ paclitaxel $(\mathrm{P})$ plus gemcitabine $(\mathrm{G})$ with $\mathrm{DD} \mathrm{AC} \rightarrow \mathrm{P}$ and with docetaxel, doxorubicin, and cyclophosphamide (TAC) in women with operable, node-positive breast cancer. J Clin Oncol 2012; 30 (Suppl.): Abstr. LBA1000

36 Rugo HS, Barry WT, Moreno-Aspitia A et al. CALGB 40502/NCCTG N063H: randomized phase III trial of weekly paclitaxel (P) compared to weekly nanoparticle albumin bound nab-paclitaxel (NP) or ixabepilone (Ix) with or without bevacizumab (B) as first-line therapy for locally recurrent or metastatic breast cancer (MBC). J Clin Oncol 2012; 30 (Suppl.): Abstr. CRA1002

37 Gennari A, Stockler M, Puntoni $M$ et al. Duration of chemotherapy for metastatic breast cancer: a systematic review and meta-analysis of randomized clinical trials. J Clin Oncol 2011; 29: 2144-2149

38 Lux MP, Fasching PA, Loehberg CR et al. Health services research and health economy - quality care training in gynaecology, with focus on gynaecological oncology. Geburtsh Frauenheilk 2011; 71: 1046-1055

39 Lux MP, Reichelt C, Wallwiener D et al. Zoledronic acid - a cost-effective adjuvant therapy for patients with breast cancer. Results of the Zome$\operatorname{ta}^{\circledR}$ cost-utility model for the German healthcare system based on the results of the ABCSG-12 study. Onkologie 2010; 33: 360-368 
40 LLombarto A, Frassoldati A, Paija $O$ et al. Effect of zoledronic acid on aromatase inhibitor-associated bone loss in postmenopausal women with early breast cancer receiving adjuvant letrozole: E-ZO-FAST 36month follow up. ASCO Breast Cancer Symposium 2009

41 Lux MP, Reichelt C, Wallwiener D et al. Breast cancer: bisphosphonates in the adjuvant - also from a health point of view a useful therapy. Geburtsh Frauenheilk 2010; 70: 592-595

42 Xue M, Fishman P, Botteman M. Cost-effectiveness of zoledronic acid (ZOL) in postmenopausal women with early breast cancer receiving adjuvant letrozole. J Clin Oncol 2012; 30 (Suppl.): Abstr. 553

43 Hughes LL, Wang M, Page DL et al. Local excision alone without irradiation for ductal carcinoma in situ of the breast: a trial of the Eastern Cooperative Oncology Group. J Clin Oncol 2009; 27: 5319-5324

44 Lück HJ, Lux MP. Aktuelle Empfehlungen zur Therapie primärer und fortgeschrittener Mammakarzinome State of the Art 2012. In: Brustkrebs: Spezielle Situationen. Kommission Mamma, Arbeitsgemeinschaft Gynäkologische Onkologie e.V., Deutsche Gesellschaft für Gynäkologie und Geburtshilfe e.V., Deutsche Krebsgesellschaft e.V.; 2012

45 Reeder-Hayes KE, Wheeler SB, Biddle AK. Cost-effectiveness of adjuvant radiotherapy for older women with early hormone-receptor positive breast cancer. J Clin Oncol 2012; 30 (Suppl.): Abstr. 6096
46 Wang Z, Li X, Faria C. Characterization of health care resource utilization and costs in women with metastatic breast cancer in Medicaid. J Clin Oncol 2012; 30 (Suppl.): Abstr. e16521

47 Refaat T, Choi M, Gaber G et al. Cost-effectiveness analysis using a Markov model assessing the addition of bevacizumab to paclitaxel in HER-2-negative metastatic breast cancer patients. J Clin Oncol 2012; 30 (Suppl.): Abstr. 1069

48 Twelves C, Loesch D, Blum JL et al. A phase III study (EMBRACE) of eribulin mesylate versus treatment of physician's choice in patients with locally recurrent or metastatic breast cancer previously treated with an anthracycline and a taxane. J Clin Oncol 2012; 28 (Suppl.): Abstr. CRA1004^

49 Montero AJ, Avancha KKVR, Gluck S et al. Cost-effectiveness analysis of eribulin (E) versus treatment of physician's choice (TPC) in patients (pts) with pretreated metastatic breast cancer (MBC). J Clin Oncol 2012; 30 (Suppl.): Abstr. e16525

Deutschsprachige Zusatzinformationen online abrufbar unter: www.thieme-connect.de/ejournals/toc/gebfra. 